\title{
EMPLOYMENT EXPERIENCES OF POST GRADUATE STUDENTS IN KWAZULU-NATAL: AN INTERSECTION OF QUALIFICATIONS AND EMPLOYABILITY IN THE LABOUR MARKET
}

\author{
N. C. Ndebele* \\ e-mail:210554970@stu.ukzn.ac.za
}

\author{
J. Ndlovu* \\ e-mail: Ndlovuj1@ukzn.ac.za \\ *School of Social Sciences \\ University of Kwa-Zulu Natal \\ Durban, South Africa
}

\section{ABSTRACT}

The past decade has seen a sturdy increase in the literature on higher education and policy discourse on the absorption of graduates in the labour market. To understand students', post graduate experiences, a case approach was adopted. Participants comprised of employed and unemployed students who were registered at the University of Zululand in 2016 particularly those who successfully completed their undergraduate degree in any South African tertiary institution. An empirical study shows that Graduates lack job market information and experience to enable them to undertake this arduous journey. Unemployment and under employment was found to be due to lack of certain personal attributes, serious skills mismatch and general lack of capability. The article argues that there is a gap between qualifications and capability-employment in the labour market. Higher education institutions and industry should bridge this gap by emphasising on labour market needs, individual attributes and social inequalities in programme design.

Key words: labour market, employment, graduates, perceptions, education

\section{INTRODUCTION}

To become competitive, post-industrial economies have become knowledge driven for them to remain competitive (Moreau and Leathwood 2006). Hence enhancing skills of the work force has become the order of the day in increasing national prosperity. As a result, most governments have put pressure on educational institution to increase human capital by increasing graduate employability. The transition of graduates from college to the world of work has posed many challenges. Today there is no match between the sacrifices made and the returns (Taylor 2005). Hence different returns have become a central source of socio-economic problems our time. When a person is willing to work and is able to work, there is no work, the situation is referred 
to as unemployment (Swanepoel and Van Zyl 1999). The issue of graduate unemployment does not only affect South Africa but also other countries around the world. National security has also been threatened by the propensity challenge as governments seek to establish legitimate order. A case in point is in some parts of North Africa, where Egypt, Tunisia and Libya experienced youth violent uprisings spearheaded by most unemployed graduates. Hence unemployment has become widespread among those students who have finished their university studies (National Treasury 2011). Most of the graduates who are unemployed have graduated from previously disadvantaged universities. The gap has increased over the years since most of the graduates lack basic skills (Development Policy Research Unit 2006, 1). Statistics SA (2015) shows that the majority of people who are unemployed young. So, youths who were unemployed between 2008 and 2014 aged between 15-24 years constituted more than 50 per cent while those who were aged between 25-34 years was above 29 per cent (Statistics SA 2014a). This implies that youths are not getting adequate skills and knowledge for them to be integrated into the job market. To address this challenge, the government has adopted a multidimensional strategy to deal with unemployment. Many studies have shown that education plays an important role in employment creation (GCE 2010). Thus, to produce citizens who can contribute immensely to economic growth and development, there is need to provide the right education (Global Campaign for Education 2010, 2). Nevertheless, new developments are emerging in literature. The debate on the discourse of graduate employment narrowly focusses on human capital and employability without looking at the preparedness of individual learners undertaking the arduous journey (Lourens and Fourie-Malherbe 2016). In South Africa, the conventional employability accounts are problematic as they fail to understand the leaner on the pathway to future employment. For instance, the individual's selfmanaged approach, through a reiterative series of developmental stages to employability (Beukes 2009). Hence, the labour market is clamouring for high quality and relevant education (Statistics SA 2002, 25). However, there is no guarantee that education can lead to employment. Little is known about the perceptions of post graduate students on their actual or anticipated post-graduation employment. Therefore, what are the perceptions of graduates on graduate employability? Do higher education institutions subscribe to the dominant discourse on graduate employability? To answer the research questions, this article examines the level of intersection between qualifications and employability in the labor market.

\section{FRAMING GRADUATE (UN)EMPLOYABILITY IN HIGHER EDUCATION INSTITUTIONS}

In recent decades, the higher education system in the UK has undergone major transformations 
(Moreau and Leathwood 2006). As a result, mass higher education remains the privilege of the middle class. Changing employment structures have made degrees a pre-requisite for employment. In some cases, some jobs that did not require degrees have made working insecure and less predictable (Scott 1995; Heery and Salmon 2000). High unemployment has become a global problem. For instance, unemployed youths between 15-25 years have been found to be three times higher than unemployed adults (ILO 2006). South Africa is fast becoming one of the highest countries with unemployed youths. A study on post-graduates and employment opportunities creation is not only germane by timely given that South Africa is currently experiencing uncertain levels of fees must fall uprisings throughout the country in 2016. Unemployment has been studied by various researchers, of note, Naong (2011), concluded that the cause of unemployment among graduates was that some chose wrong careers due to the weak education system, as a result they struggle to find employment. He concluded that in order to solve the unemployment problem, schools should promote a culture of entrepreneurship among learners.

\section{Transforming qualifications in higher education}

A study that was conducted by Sha (2006) on students who did computer science in Malaysia concluded that unemployment was based on both the graduates and employers' perspectives. His results show that on one hand, unemployed graduates blamed employers for lack of employment opportunities. On the other hand, employers viewed computer science graduates as having a negative attitude towards work, hence employers were reluctant to hire them. In the banking sector, Oluwajodu, Greyling, Blaauw and Kleynhans (2015) revealed that graduate unemployment in South Africa was a result of employers' perceptions of the institutions attended by graduates. Other factors reinforced by Ewert included lack of soft skills, cultural fit and management skills that would enable them to lead organisations competitively (Lourens and Fourie-Malherbe 2016). Thus, his study found that the university based skills were inadequate and some were too academic and irrelevant for the graduates to meet the job-skills requirements. He recommended that other skills should supplement the university based skills.

Pauw, Oosthuizen and Van der Westhuizen (2006) noted that there has been an increase in the number of students enrolled in tertiary institutions. However, they noted that in the past ten years, unemployed youths constituted the highest number. They recommended that students should be encouraged to focus on careers with better employment opportunities, learners should be adequately prepared to enter into the labor market, and an investment in soft skills. In a study that was conducted by the Development Policy Research Unit concluded that due to emigration, South Africa's largest companies have lost crucial skills during the past decade. Consequently, 
most companies have resorted to considering applicants with skills and experience. In another study conducted by Moleke (2000), it was found that students who graduated with degrees that had a professional focus tended to get employed faster than those with general degrees. Fields such as engineering and medical science qualifications were absorbed into the labor market faster than other fields such as humanities and arts. For instance, humanities and arts do not feed directly professional occupations, hence these graduates took longer to find jobs compared to natural and management sciences (Moleke 2000).

\section{Demand for higher education in South Africa}

Altbeker and Storme (2013) conducted a study on graduate unemployment in South Africa, they noted that employers considered university degrees when hiring, however to reduce graduate unemployment the expansion of university education should be supported by relevant education policies. They further observed that public universities will struggle to meet demand if their growth and expansion is not appropriately supported (Altbeker and Storme 2013, 2). Even though graduate unemployment has been extensively studied in South Africa, gaps in literature still exist since most of the recommendations focus only on education. Whilst developing an appropriate education system is key to reducing graduate unemployment, there are many variables affecting graduate (Lie 2007). So, solutions and other problems contributing to graduate unemployment need to be examined carefully. The literature shows that studies exploring the perceptions of graduates on employment are inadequate. Most studies have focused on graduates' employment from the employer's perspective there by limiting researchers and policy makers with information. In this article, we sought to explore the challenges faced by graduates in securing employment with particular focus in KwaZulu-Natal.

\section{UNEMPLOYMENT AND UNDER EMPLOYABILITY CHANGING LAND SCAPE}

Over the years, the educational achievement has risen which has resulted in the change in labour force requirements. Thus, the increased supply of educated workers is not in tandem with the job structure. Other scholars claim that over education has exacerbated the problem in labour market. Freemen (1976) analysed the consequences of over education and concluded that the increasing number of people with university qualifications has forced graduates to settle for inferior jobs. He further noted that the demand for labour has decreased while the supply has increased in the labour (Ge Zhou 2010).

Similarly Rumberger (1981) views "over education in one of three ways: as a decline in the economic position of educated individuals relative to historically higher levels meaning those with university qualifications are economically unstable as under fulfilled expectations 
of the educated with respect to their occupational attainments, meaning one would expect graduates to be employed rather than unemployed or; where workers possess greater educational skills than the positions available to them require". However, others (Vroom 1964; Sheppard and Herrick 1972) cautioned on the adverse effects of over education on individual productivity. They further noted that over education may adversely affect workplace behaviours which may increase job dissatisfaction and health problems. Thus, if individual's characteristics and the job characteristics do not match, this may cause job dissatisfaction.

\section{The labour market and employability discourse}

Doeringer and Piore, (1970) on their theory of labour segmentation proposes "that labour market is segmented into primary and secondary markets, differentiated mainly by the education background requirement for applicants and the correlation between education background and income". Pauw, Oosthuizen and Van der Westhuizen (2006) suggest that "graduates select jobs and prefer to remain unemployed until they get their dream employment". The labour in South Africa can be divided into three, namely, the primary sector, the secondary sector and the tertiary sector. The primary sector is involved in exploiting basic raw materials. This economic sector is made up of industries that deal with raw materials such as fishing and forestry, agriculture and mining. The secondary sector processes basic material obtained from the primary sector. These economic sectors include construction, manufacturing and electricity generation. Lastly, the service sector which is the tertiary sector is made up of government services, retail and wholesale operations, finance and real estate.

\section{Employability and the need for relevant skills}

The educational requirements in the primary and secondary sectors are specialised hence both can be considered as secondary labour market. However, in this segment university qualifications are not a top priority. Areas such as fishing and forestry do not demand high level skills as compared to the tertiary sector. In the tertiary sector certain skills are required. In this sector, university education is a prerequisite, working conditions and welfare are good, jobs are stable and there is a relationship between the income and education. Even though the university education can increase job prospect, in South Africa most people who are unemployed are young graduates. Lourens and Fourie-Malherbe (2016) claims that the gabs between the types of workers supplied and those demanded by the economy is a clear indication of a structural problem. 


\section{METHODOLOGY}

The article explored the perceptions of post-graduates on employment opportunities in the North Coast of KwaZulu Natal. The respondents were University of Zululand graduates who were registered as post-graduate students in the year 2016. The respondents comprised of postgraduates from all faculties at the University of Zululand registered as Honors, Masters and $\mathrm{PhD}$ students. Non probability sampling was employed and the questionnaire contained open, closed and Likert scale questions. The sample consisted of 74 post-graduates from a population of 80 post-graduates. A total of 74 respondents participated in the study, 20 respondents were from the Faculty of Admin and 18 were from the Faculty of Education, 19 from the Faculty of Art, 20 from the Faculty of Admin, Law and Commerce, and 17 from the Faculty of Science. The University of Zululand was chosen since it is the only rural based comprehensive tertiary educational institution in KwaZulu Natal which serves a large rural population of uMkhanyakude, Zululand and uThungulu District. University of Zululand, KwaDlangezwa Campus was chosen because it the only campus offering post-graduates studies. The collected data was coded keywords into thematic codes and analysed using grounded theory.

\section{FINDINGS}

The findings presented below shows that graduate unemployment should not be generalised since the field of study has a direct bearing on employment opportunities. It was also revealed that those in the humanities (Faculty of Arts) are less absorbed in the employment sector as compared to those in education, sciences and commercials. Most of the participants had first degrees followed by Honours and Masters respectively.

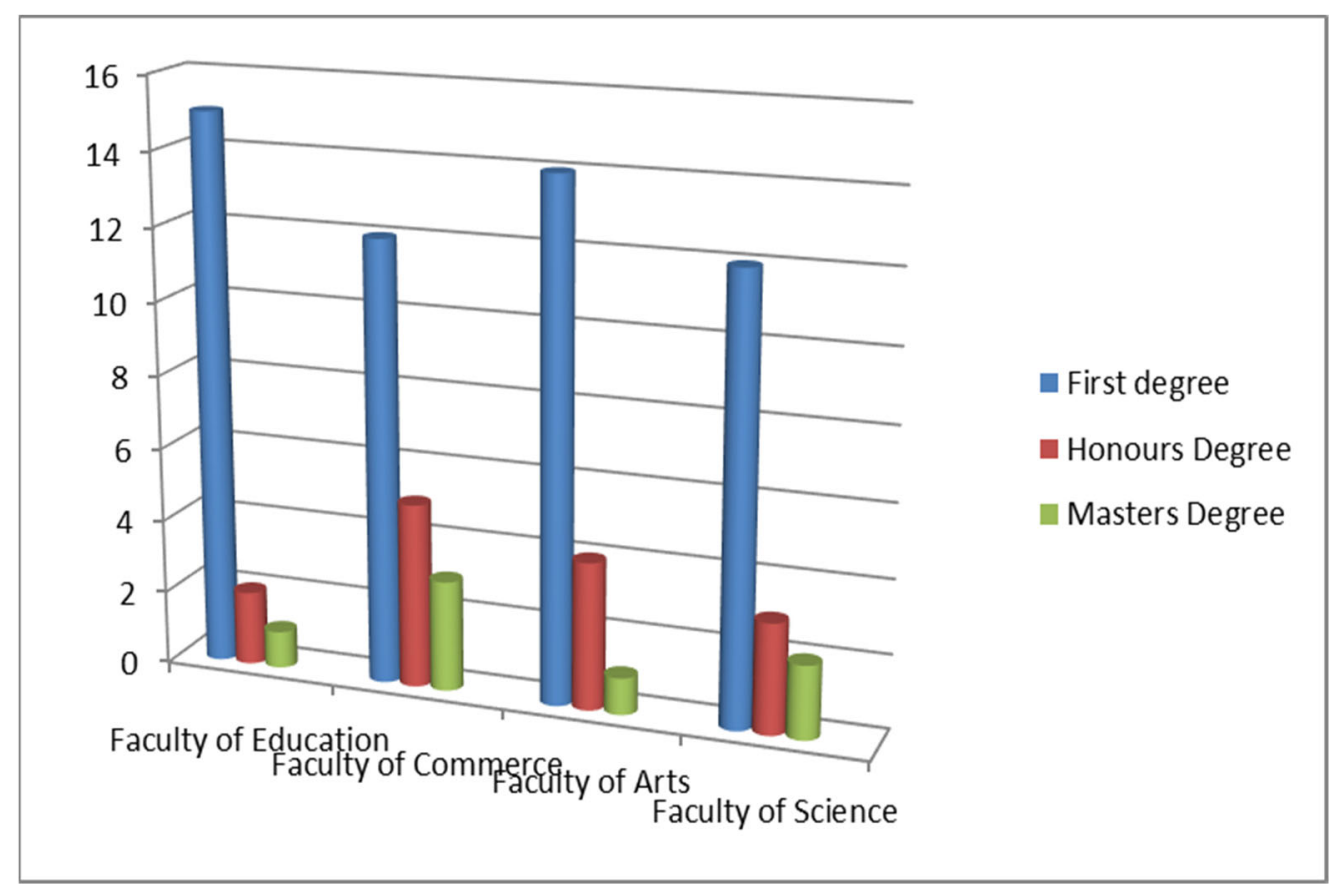

Figure 1: Percentage distribution of level of education per field of study 
Figure 1 also indicates that some disciplines i.e. sciences, education, and commerce. And humanities were the most represented in the responses. With high numbers of students with first degrees, the question of individual students becoming active agents in developing and sustaining their employment opportunities becomes relevant. Similarly, in his study Moleke (2006) concluded that unemployment was higher in Arts and Humanities graduates compared to Commerce, Science and Education graduates. If humanities students constitute the highest percentage of graduate students who are unemployed, why is it that there is no correlation between first degree throughput and post graduate enrolment? For students to be able to increase their chances of employment, they need to be flexible, adaptable and should become lifelong learners (Beukes 2009). Hence, graduates should be able to learn and retool them themselves with knowledge and competencies associated with personal learning and development throughout their careers (Van der Hejden 2002; Savickas 2009).

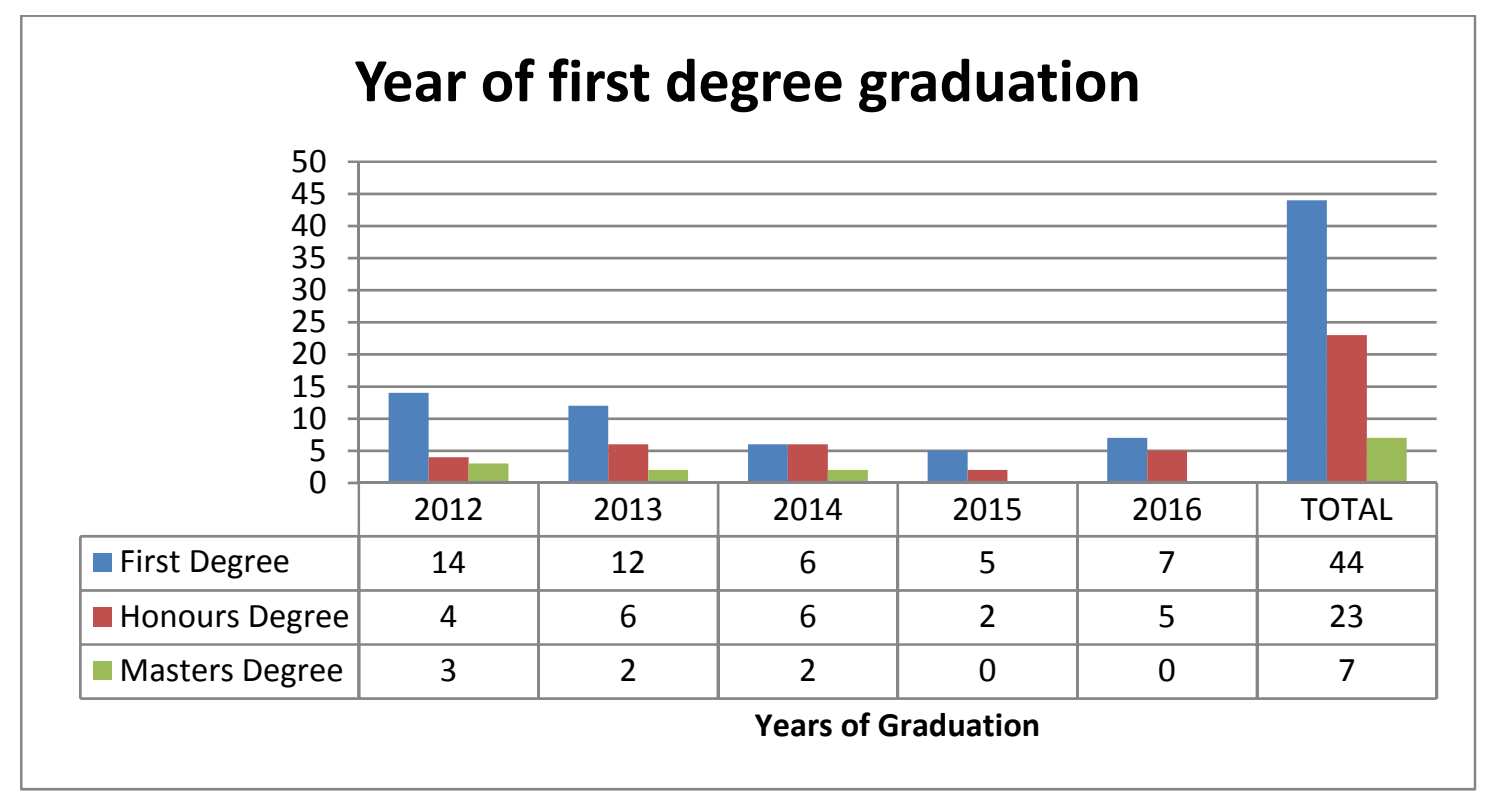

Figure 2: Percentage distribution of year of first degree graduation

The above table shows the participants based on their level of education. The large percentage ( $28 \%$ ) of graduates were from the faculty of education who first graduated in in 2012 , followed by 26 per cent in 2013, 2015 and 2016 had 16 per cent and nine per cent respectively. Looking at the construct of employability, one has to understand the individual's perspective, and benefits to the wider environment. So, employability relates to knowledge skills, attributes and understanding that assists individuals to choose secure and satisfying occupations (Pool and Sewell 2007). The evidence presented confirms the view that attaining higher postgraduate qualifications will increase chances for individuals to be absorbed into the labour market. 


\section{Graduates' perceptions on employability}

Table 1 shows graduates lack career guidance $(42 \%)$ hence career choices have a bearing on graduate (un)employment. Twenty-six per cent of the respondents strongly disagreed that the government initiatives were ineffective. Respondents felt that the relationship between universities and companies (41\%) was mutual. However, 305 felt that there was a skills mismatch between qualifications and labour market needs. The results show that individuals do not channel their competencies in sustaining and accessing employment in a turbulent and highly competitive market (Beukes 2009). As argued in the study, career guidance assists to help prospective students in choosing professions that are market oriented.

Table 1: Perceptions of Graduates' on employment opportunities

\begin{tabular}{|l|c|c|c|c|c|}
\hline $\begin{array}{c}\text { Perceived causes of graduates' } \\
\text { unemployment }\end{array}$ & $\begin{array}{c}\text { Strongly } \\
\text { Agree }\end{array}$ & Agree & $\begin{array}{c}\text { Strongly } \\
\text { Disagree }\end{array}$ & Disagree & $\begin{array}{c}\text { Uncertain/ } \\
\text { Not sure }\end{array}$ \\
\hline Lack of career guidance & $31(42 \%)$ & $15(20 \%)$ & $8(11 \%)$ & $17(23 \%)$ & $3(4 \%)$ \\
\hline $\begin{array}{l}\text { Ineffectiveness of government } \\
\text { initiatives }\end{array}$ & $10(14 \%)$ & $18(24 \%)$ & $19(26 \%)$ & $12(16 \%)$ & $15(20 \%)$ \\
\hline $\begin{array}{l}\text { Relationship between universities } \\
\text { and companies }\end{array}$ & $30(41 \%)$ & $14(19 \%)$ & $12(16 \%)$ & $18(24 \%)$ & - \\
\hline Skills shortage and mismatch & $18(24 \%)$ & $22(30 \%)$ & $17(23 \%)$ & $12(16 \%)$ & $5(7 \%)$ \\
\hline
\end{tabular}

The findings show the results on the graduates' opinions regarding unemployment. The opinions differ from faculty to faculty depending on the faculty needs. From the above results, unemployment was caused by lack of career guidance (42\%) and 26 per cent strongly disagreed that the government initiatives to curb unemployment were ineffective. Whilst others agreed that the government initiatives are not effective (24\%) in preparing them with skills that will help them survive the working environment, the results suggest that programmes like internships and graduate programs are relevant in equipping graduates with experience and skills needed in the working environment. The other issue was that 30 per cent of the respondents strongly agreed that there was a relationship between universities and companies but Skills shortage and mismatch 30 per cent presents a challenge in the labour market.

\section{Intersection of qualifications and graduate attributes}

In this article it was observed that there has been an increase in the number of graduates with tertiary qualifications. Recently, a number of jobs that previously did not require a degree, are now filled by degree holders. A number of factors were cited such as, lack of experience (54\%). See Table 2 . 
Table 2: Graduates perceptions on employment opportunities

\begin{tabular}{|l|c|c|}
\hline $\begin{array}{c}\text { Perceived causes of graduates' } \\
\text { unemployment }\end{array}$ & Agree & Disagree \\
\hline Lack of job experience & $54 \%$ & $46 \%$ \\
\hline Corruption and nepotism & $85 \%$ & $15 \%$ \\
\hline Institutions attended & $95 \%$ & $5 \%$ \\
\hline Lack of job market information & $48 \%$ & $52 \%$ \\
\hline Lack of job search capabilities & $93 \%$ & $7 \%$ \\
\hline
\end{tabular}

The results are similar to Du Toit (2012)'s findings on unemployed youth in South Africa who claims that almost three quarters $(74,5 \%)$ i.e. 4,1 million of the unemployed youth indicated that they had never worked for pay, profit or family gain. Hence, lack of previous work experience will have a considerable effect on their efforts to seek and attain work in future. Similarly, for one to be able to fill in a vacancy, "firm require a person with some form of work experience and the ability to, at least to some degree, work independently" (Pauw et al. 2006). This view is supported by Mlatsheni (2007) and the Manpower Group (2012) who stress on the match between certain individual attributes and the job characteristics. Hence, many employers are sceptical about hiring the youth without any form of work experience. Corruption and nepotism $(85 \%)$ was found to be a dominant factor contributing to graduate unemployment. Some graduates were of the opinion that having the right people by your side can often increase job prospects. For instance, Msimanga $(2013,87)$ found that "about 5.8 per cent of women perceived lack of connections as one of the obstacles to entry in the labour market". Thus, Institutions attended contribute to graduate unemployment (95\%). The interesting finding was based on the institution of higher learning attended, it seems employers are using the University attended as a bench mark. Notably, Pauw et al. (2006) also reported that graduates' inability to deal with the interview processes and lack of infrastructure to support graduates' recruitment fairs were cited as some of the reasons why employers prefer to recruit graduates from certain higher education institution and not others. Of the surveyed graduates, about 68 per cent of the respondents believe that lack of job market information is one of the causes of unemployment. Similarly, Du Toit, (2003) and Swanepoel and Van Zyl, (1999) decried lack of information about the labour market for graduates. Thus, young people lack knowledge of what the world of work is actually like (Manpower Group 2012). The majority (93\%) of the respondents were of the opinion that if you are lacking job search capability, that can contribute to graduate unemployment. Job search capabilities include among other things, the lack of experience regarding job application processes, inability to write a comprehensive curriculum vitae, lack of writing and interpersonal skills, interview preparedness and interview response skills, location, lack of financial resources and access to computers as the obstacles to finding jobs 
(Du Toit 2003; Msimanga 2013).

\section{DISCUSSION}

The term employability has been used since the early twentieth century, its meaning changing overtime (Moreau and Leathwood 2006). Over the decade, term has shifted focus considering the global knowledge driven and competitively driven economies. For instance, the notion of job for life has diminished, scholars now talk about employment for life. In South Africa graduate employability has become a driving force to the National Development plan (NDP). Higher education institutions are expected to drive knowledge production and contribute to economic growth. Graduates employability has become the corner stone for a bigger strategy to widen the skills base for the youth. Given the investment made to public institutions, employment of graduates after graduation has become a prerequisite (Baldry 2015; Holmes 2013). Nevertheless, the results show that the majority of graduates were of the opinion that the following factors contributed to unemployment namely; lack of facilities; lack of experience; a high rate of corruption and nepotism in the government sector; lack of market information; and a mismatch of skills and a lack of job search capabilities. Using McGrath et al.'s (2017) words, poverty tends to result in a more brittle horizon of aspirations for individual communities so they cannot imagine, let alone achieve, what might be possible in other circumstances. In this article, employability was constructed as primarily a matter of an individual's skills (Moreau and Leathwood 2006). Therefore, for one to be employable, certain attributes have to be present in the individual. These vary from, basic skills to do the job, to knowledge attitudes, behavior and deportment. The way graduates present themselves to possible employers determines their chances of being employed (Jackson 2014). The article revealed that most of the unemployed graduates were predominantly students of African origin who were at honors level and below. The most affected students were from the Faculties of Commerce and Arts which implies that employment opportunities for students graduating from the University of Zululand in these disciplines was gloomy. Arguing from a policy discourse of employability, post graduate studies should equip students with a set of skills, understandings and personal attributes (key skills, cognitive skills and subject specific skills). There is a close relationship between personal circumstances and the labour market environment. Hence, graduates' choice of employment should benefit themselves, the workforce, the community and the economy (Yorke 2004). Higher education institutions play a vital role in aligning programme outcomes in terms of knowledge and understanding the student will be expected to have upon completion (Moreau and Leathwood 2006). However, drawing from human capital theories and employment policy discourses, it seems there is limited recognition of the determinants of labour markets and 
occupational structures let alone the way the graduate opportunities are framed.

Whilst employment opportunities exist for graduates in the labour market, traditional occupational rugs have become inadequate to absorb the increasing numbers of graduates churned out by universities. Other factors that can exacerbate the problem include, a lack of facilities in rural areas like libraries and relevant government education policy. Of note is the fact previously disadvantaged groups have no social networks. Some studies have shown that access to social networks can facilitate successful labour market insertion (McGrath 2017). It can be argued that formal credentials have become an unreliable predictor of success in adaptable organisations of post-industrial society (Scott 1995). So, over and above credentials, knowledge and skills, personal qualities should embrace professional disciplines (Streitwieser 2014; Wilkens, Balakrishnan and Huisman 2012). Caution has to be taken not to over simplify the complexity of specialist and technical occupations over personality and skills. As noted by Moreau and Leathwood, (2006) the issue of discourse of skills has attracted much controversy. Some have argued that skills reflect a narrow view to education. While others have problematized and socially constructed skills and concluded that they are a threat to academic freedom (skills are gendered and channel people to narrow specific occupations with no room for growth and develop) (Lourens 2016). The article notes that the government has made a tremendous effort to address unemployment. Such initiatives include the provision of inservice/internships for graduates to enable them to be integrated into the labour market easily. Recent debates claim that (un)employability is now seen as an individual problem hence the shift to equipping individuals for the knowledge-driven, increasingly competitive economy and on encouraging them to take responsibility for their own employment/employability (Moreau and Leathwood 2006; McGrath and Powell 2015). Critics have argued that governments are now using employability discourse to remedy market failures. McGrath et al. (2017) argues that alternative readings on employability reflect an Anglo-Saxon tendency to think in terms of atomistic individuals who are solely responsible for their own employability thereby down playing the role of labour market, responsibility of employers and politicians in influencing employment opportunities. Although there is acknowledgement in government policy discourses opportunities for different categories of people exist, individual agency can be denied by structured employment opportunities (Hollywood et al. 2012; Hinchcliffe 2013). Hence the intersection of qualifications and employability in the labour market is blurred.

\section{CONCLUSION}

Over the past decade there has been a sturdy increase in the literature on higher education and policy discourse on the absorption of graduates in the labor market. The article critically 
examined the intersection of qualifications and employability in the labor market. Graduates employability has become the corner stone for a bigger strategy to widen the skills base for the youth. Hence, South Africa has seen an increase in the number of graduates from higher education institutions. For one to be employable, certain attributes have to be present in the individual. These vary from, basic skills to do the job, to knowledge, attitudes, behaviour and self-deportment. The evidence showed that the way graduates present themselves to possible employers determines their chances of being employed. So, over and above credentials, knowledge and skills, personal qualities should embrace professional discipline. While university education has focused on "massification", caution has to be made on over education as this may lead to lower individual productivity and increase job dissatisfaction. Consequently, over education may adversely affect workplace behaviours which may lead to a deterioration in health. Therefore, attention has to be taken not to over simplify the complexity of specialist and technical occupations over personality traits and skills. The findings from this article confirm that transitioning to higher education presents its own persistent challenges considering unemployment and underemployment. Educated graduates may have problems finding employment after graduation because of mismatch between the labor markets requirements and educational qualifications. For graduates to become valuable assets in the labour market, industry, government and educational institutions should design relevant curricula that would prepare graduates for employment for life as opposed to jobs for life. The contribution of the article lies within the graduate employment discourse. It unravels recent debates that have shifted from obtaining mere qualifications to the development of relevant work identities that increase employment chances. Thus, higher education institutions are expected to drive knowledge production and contribute to economic growth. While recent debates claim that (un)employability is now seen as an individual problem, shifting to equipping individuals for a knowledge-driven and increasingly competitive economy will encourage them to take responsibility for their own employment/employability. Although there is acknowledgement in government policy discourses opportunities for different categories of people exist, individual agency can be denied by structured employment opportunities. Unemployment and under employment was found to be due to lack of certain personal attributes, serious skills mismatch and general lack of capability. The article argues that there is a gap between qualifications and capability-employment in the labour market. Conclusions are that the rise in educational attainment has increased the graduate labour force. So, higher education institutions and industry should bridge this gap by ensuring that the university curricula emphasise on labour market needs, individual attributes and social inequalities in programme design. 


\section{REFERENCES}

Altbeker, A. and E. Storme. 2013. Graduates unemployment in South Africa: A much exaggerated problem. Centre for Development and Enterprise.

Baldry, K. 2015. Graduate unemployment in South Africa: Social inequality reproduced. Journal Education and Work July: 1-25.

Beukes, C. 2009. The relationship between employability and emotional intelligence. Unpublished research report, Department of Industrial and Organisational Psychology, University of South Africa, Pretoria.

Development Policy Research Unit. 2006. Unemployment, education and skills constraints in postapartheid South Africa. DPRU Working Paper 07/120, Development Policy Research Unit, Cape Town. An overview of the youth labour market since 2008. Monitoring the performance of the South African labour market. Factsheet 7, Development Policy Research Unit, Cape Town.

Du Toit, R. 2003. Unemployed youth in South Africa: the distressed generation? Paper presented at the Minnesota International Couseling Institute (MICI), 27 July to 1 August 2003.

Du Toit, M. 2012. Job creation: Generating growth and opportunities. www.deloitte.com/assets/DcomSouthAfrica (Accessed 5 April 2019).

Doeringer, P. and M. Piore. 1972. Internal labor markets and manpower analysis. Lexington, Mass.

Freeman, R. B. 1976. The Overeducated American. New York: Academic Press

GCE see Global Campaign for Education.

Global Campaign for Education. 2010. The worst places in the world to be a school child in 2010. http://www.campaignforeducation.org/docs/reports/1 goal/1Goal\%20School\%20Report.Pdf. (Accessed 11 September 2018).

Heery E. and J. Salmon. (Ed.). 2000. The insecure workforce. London: Routledge.

Holmes, L. 2013. Competing perspectives on graduate employability: Possession, passion or process? Studies in Higher Education 38(4): 538-554.

Hinchcliffe, G. 2013. Employability: A capability approach. In Human development and capabilities, ed. A. Boni and M. Walker, 82-96. London: Routledge.

Hollywood, E., V. Egdell, R. McQuaid and Michel-Schertges, D. 2012. Methodological issues in operationalising the capability approach in empirical research: An example of cross-country research on youth unemployment in the EU. Social Work and Society. http://nbnresolving.de/urn:nbn:de:hbz:464-sws-182

ILO. 2006. Global employment trends for youth. Geneva: International Labour Organisation.

Jackson, D. 2014. Skill mastery and the formation of graduate identity in Bachelor graduates: Evidence from Australia. Studies in Higher education: 1-20.

Lie, K. 2007. Employer perception on graduate literacy in higher education in relation to the workplace. http://www.esp-world.info/Articles_20/DOC/Koo_vp_employer_Journal18Oct09.pdf (Accessed 20 September 2018).

Lourens, E. 2016. From graduate to employee: Exploring the journeys of first time entrants into the labour market. Unpublished doctoral thesis. Stellenbosch.

Lourens, E. and M. Fourie-Malherbe. 2016. The employability of higher education graduates: Are qualifications enough? http://www.econ3x3.org/article/employability-higher-educationgraduates-are-qualifications-enough (Accessed 19 September 2017).

Manpower Group. 2012. "Youth unemployment challenge and solutions: What business can do now." http://www.youthpolicy.org/library/wp-content/uploads/library/2012_Youth_Employment BusinessSolutions.pdf (Accessed 19 September 2017).

McGrath, S., R. Madzivab and J. Thondhlana. 2017. Rethinking the employability of international graduate migrants: Reflections on the experiences of Zimbabweans with degrees from England. Journal of Further and Higher Education 41(2): 238-259, 
McGrath, S. and L. Powell. 2015. Vocational education and training for human development. In Routledge Handbook of International Education and Development, ed. S. McGrath and Q. Gu. London: Routledge. Forthcoming.

Mlatsheni, C. 2007. A survey of youth labour market trends. Draft paper prepared for Human Sciences Research Council.

Moleke T. P. 2000. Public private partnerships and service delivery in Queenstown. Masters in Management thesis. University of the Witwatersrand, Johannesburg, South Africa.

Moleke, P. 2006. Finding work: Employment experiences of South African graduates. Cape Town: HSRC Press.

Moreau, M. and C. Leathwood. 2006. Graduates' employment and the discourse of employability: A critical analysis. Journal of Education and Work 19(4): 305-324.

Msimanga, T. H. 2013. Determining the factors that affect female unemployment in a South African township. Vanderbijlpark: NWU. (Dissertation-MCom).

Naong, M. 2011. Promotion of entrepreneurship education: A remedy to graduates and youth unemployment. Journal of Social Science 28(3): 181-189.

National Treasury. 2011. Confronting youth unemployment in South Africa. Discussion Paper for public comment.

Oluwajodu, F., L. Greyling, D. Blaauw and E. P. J. Kleynhans. 2015. Graduate unemployment in South Africa: Perspectives from the banking sector. South African Journal of Human Resource Management 13(1): 1-9.

Pauw, K., H. Bhorat and S. Goga. 2006. Graduate unemployment in the context of skills shortages, education and training: Findings from a survey. http://papers.ssrn.com/sol3/papers. cfm?abstract_id=961353 (Accessed 26 June 201).

Pauw, K., M. Oosthuizen and C. van der Westhuizen. 2006. Graduate unemployment in the face of skills shortages: A labour market paradox. Accelerated and Shared Growth in South Africa: Determinants, Constraints and Opportunities 18-20 October 2006. The Birchwood Hotel and Conference Centre Johannesburg, South Africa.

Pool, D. L. and P. Sewell. 2007. The key to employability: Developing a practical model of graduate employability. Education and Training 49(4): 277-289.

Rumberger, W. R. The rising incidence of over education in the U.S. Labour market. Economics of Education Review 1(3): 293-314.

Savickas, M. 2009. Pioneers of vocational guidance movement: A centennial celebration. The CDQ: Special section: The $100^{\text {th }}$ Anniversary of vocational guidance 57(3): 259-273.

Scott, R. W. 1995. Institutions and organizations. Thousand Oaks, CA: Sage.

Sha, N. 2006. Are graduates to be blamed? Unemployment of computer science graduates in Malaysia. http://aabss.org/Perspectives2008/ AABSS2008Article6 N ORSHIMAZSHAH.pdf

Sheppard, H. L. and N. Q. Herrick. 1972. Where have all the robots gone? New York, Free Press.

Statistics South Africa. 2014a. Employment, unemployment, skills and economic growth: an exploration of household survey evidence on skills development and unemployment between 1994 and 2014. Pretoria.

Stats SA (Statistics South Africa), 2002. General Household Survey; Stats SA (Statistics South Africa), 2009. General Household Survey.

Statistics South Africa. 2015. Quarterly labour force survey 2015. Pretoria

Streitwieser, B. (Ed.). 2014. Internationalisation of higher education and global mobility. Oxford: Symposium.

Swanepoel, D. J. and J. S. van Zyl. 1999. Economics 2000. Cape Town: Nasou.

Taylor, A. 2005. What employers look for: The skills debate and the fit with youth perceptions. Journal of Education and Work 18(2): 201-218. 
Van der Heijden, B. I. J. M. 2002. Individual career initiatives and their influence upon professional expertise development throughout the career. International Journal of Training and Development 6(2): 54-79.

Vroom, V. H. 1964. Work and motivation. New York: Wiley

Wilkens, S., M. Balakrishnan and J. Huisman. 2012. Student choice in higher education: Motivations for choosing to study at an international Branch Campus. Journal of Studies in International Education 16(5): 413-433.

Yorke, M. 2004. Employability in the undergraduate cumulus: Some student perspectives. European Journal of Education 39: 209-227.

Zhou, Ge. 2010. Graduate unemployment in China: A market demand perspective. M and D Forum. https://pdfs.semanticscholar.org/bfea/69ebe2c0beabfc8be31e26f21b22165461a0.pdf (Accessed 26 June 2014). 